\title{
The Story of the War Gamelan Is A Story of Truth
}

\author{
HENDRA SANTOSA \\ Karawitan Department, Performing Arts Faculty, Indonesian Institute of the Arts ( ISI) Denpasar \\ J1. Nusa Indah Denpasar Bali \\ E-mail : hendrasnts@gmail.com
}

Cerita tentang gamelan yang dipergunakan dalam peperangan dianggap sebagai sebuah cerita yang ada di negeri dongeng, sebagai cerita masa lalu yang kebenarannya diragukan. Slogan ilmu sejarah yang menyebutkan tidak ada dokumen maka tidak ada sejarah merupakan sebuah ungkapan bahwa dalam sejarah tidak boleh hanya berdasarkan "katanya" atau cerita yang belum tentu benar adanya, dia harus berdasarkan fakta peristiwa sejarah terjadi, sehingga diperlukan dokumen dalam menguak peristiwa sejarah. Sebuah cerita sejarah diperlukan metode dalam proses penyusunannya metode itu dikenal dengan metode sejarah. Naskah-naskah kuno sebagai salah satu sumber sastra sejarah, banyak menyimpan peristiwa-peristiwa sejarah yang berkaitan dengan kebudayaan terutama dengan seni karawitan. Pada artikel ini yang akan dibahas adalah kata Bheri dan Mrdangga dari naskah kuno yang telah diterjemahkan ke dalam bahasa Indonesia oleh para peneliti terdahulu.

Stories about gamelan used in warfare are regarded as a character in a fairy tale, a story of the past apocryphal. The slogan of history that says no document no historical is an expression that history should not be based solely on "people said" or a story that is not necessarily true, he should be based on the facts of historical events occurred, so that the necessary documents to uncover the historical events. A historical narrative method is needed in the process of developing the method known as historical methods. The ancient manuscripts as a source of literary history, many stores historical events related to culture, especially with the musical arts. In this article will be discussed is the word Bheri and Mrdangga of two ancient manuscripts that of which have been translated into Indonesian by previous researchers.

Keyword : gamelan, war gamelan, story, mredangga, bheri

\section{INTRODUCTION}

The function of gamelan is caused by internal and external factors. Functions can be connected between an institution with the needs of a community organism (Sedyawati, 1985: 48). The music is created by people on the basis of intent to fulfill a specific purpose both physical and spiritual needs (Fernandus, 2003: 379). Achieving forms of gamelan with each variation, shows a freedom of artists creativity in realizing their creation and work in the forms of gamelan and their respective functions. Therefore anciently musical artists had the freedom to work in meeting the needs of community.

Fernandus divided the function of ensemble (see gamelan) in the ancient Javanese society into two major parts, namely the function of gamelan as a means of sacred ceremonies and as a secular spectacle. Furthermore, in secular activities, it was carried out in seven events (Fernandus, 2004: 378399). The activities are: 1) entertainment, for example in the kakawin Ghatotkacasraya 37: 7 it is 
told that villagers entertained Siti Sundari with a song, the accompaniment of the piece and percussion; 2) communication, such as in kidung Sri Tanjung VII: 38 and VIII: 38 who reported a significant event like a gathering, a sign of victory, a danger, and marriage; 3) respect, at this present moment gamelan is often used to welcome guests in a celebration; 4) the war, 5) economic, inscriptions of ancient Bali have much to say about the amount of wages to be paid; 6) dowry, in Tantric Kamandaka the king who would be married to the daughter of the duke gave betel, fan, Sangkha, kala, as a dowry (Hooykaas, 1931: 54); and 7) symbol, for society as the bearer of culture can not be separated from the symbol with an important role in the life and human behavior (Fernandus, 2004: 398).

Various stories about the war in the past, can not be separated from the use of gamelan instruments. The war Gamelan was so important in a battle that it could postpone an attack to be carried out by Raden Wijaya when he tried to usurp the throne of Jayakatwang. Kidung Ranggalawe Canto VI No. 29 states that Ranggalawe asked permission from Raden Wijaya to take the horses, flags, gong, tatabuhan, and gending of Madura. The important role of Gamelan in the war mentioned in the Old Javanese literature. In war, a set of gamelan can function as a generator of fighting spirit. But the opposite is that the sound of gamelan has also a role to frighten the enemy that can undermine morale opponent. How to tell ballad Kidung Ranggalawe told the war fought by Jayakatong forces who did not use gamelan and Raden Wijaya troops attacked using sounds to surprise the opponent. At this time in a variety of musical traditions in Indonesia, there is a performance art piece featuring a war with of course accompanied by a variety of accompanying music.

It is very interesting to discuss about war gamelan stories in the past because at that time it was possible for the use of gamelan in battle. In the Hindu concept, war is yadnya or sacrifice. It is mentioned in Bharatayudha that Yudhisthira holds power over the three worlds achieved with yadnya that is human victims of wars (rana yadnya). In Bhatarayudha many human casualties occur. The victims are essentially toward safety. A hero always puts first yadnya to carry out duty to stamp out the enemy on the battlefield (Medera, 1986: 39).

\section{RESEARCH METHODS}

History is a story or a story about an event that has occurred within a certain time. Some historical events that have passed turn out to have a deep impression, so trying to be reexpressed in the form of story or tale. Historical events such as war involving the gamelan have happened and leave traces that can be made to search again about how the actual events of the war or non war involving the gamelan happened. To meet the standards of science, a story of historical events procedures and specific process called historical method are required. If the historical method is applied correctly in the rearrangement (reconstruction) of historical events, then the resulting story will be objective and close to the actual event. By using the historical method, the story about the war gamelan is arranged in a systematic, analytical, and chronologically in chronological order.

Historical methods according to Louis Gottschalk (1975: 32), is the process of testing and critically analyzing the records and relics of the past. The historical method consists of heuristics, criticism, interpretation, and historiography, with the aim of reconstructing the past (Garraghan 1957: 33-69; Gottschalk: 1975: 17-19; Kartodirdjo 1982, Herlina, 2014: 15-60). To take the correct procedure in historical research coherent stages are necessary.

The first stage is a heuristic that becomes the first step of research by starting to collect and share data sources related to the problem being investigated, the written sources, oral sources, the object source or artifacts (Gottschalk, 1975: 35-36; Kuntowijoyo, 1995: 94-95; Herlina, 2008: 7). Written sources collected can be a source of traditional and modern sources revealing about the word of war gamelan.

The second stage is the criticism or analysis that is a test of the authenticity of the source or the so-called external criticism and testing the credibility of the source or the so-called internal criticism. Through criticism the proven authentic resources could generated and trustworthy. To generate historical fact, the source of which has been tested needs to get support from other sources (two or more) other sources that are independent of each other and becomes a trustworthy witness. Therefore it needs colaboration data with historical resources of more 
than one. Support from different sources can produce fact close to certainty or certainty of fact (Garraghan, 1957: 229; Gottschalk, 1975: 95-117; Kuntowijoyo, 1995: 98-99; Herlina, 2014: 24-34).

The third stage is the interpretation or interpretation of the facts and historical sources; the interpretation is done in two forms namely analyzes (outlining) and synthesis (unifying). Interpretation employed is the verbal and factual interpretations. Verbal interpretation is related to language, vocabulary, grammar, context, and translation. Verbal interpretation has the duty to explain the meaning of words or sentences. Factual interpretation is not based on words but on facts, and makes the facts speak without making interpretations (Garraghan, 1957: 321; Herlina, 2014: 36-55).

The last stage in the historical method is historiography. This stage is set forth in a report in the form of multidimensional writing. Report writing will be directed to form an analytical writing rather than narrative or descriptive, because the analytical writing has the ability to provide a superior explanation based on the facts disclosed (Kartodirdjo, 1993: 2).

\section{RESULTS AND DISCUSSION}

The disclosure of the war gamelan in Indonesia, was already there from the VII century taken from Chinese news as in the following description

News from Chinese travelers in the seventh century reported about the war gamelan in Indonesia. News from T'ung Tien said that to mark the war in the coun try west of Tolomo and in southeastern of ChenChow, using a musical instrument, trumpet and drums, in which the news were reported to the king of Sui dynasty, then the news from the T'ang Shu compiled by Au Yang Hsiu telling the same thing, that the above country as a sign of war the trumpets and drums are sounded (Soetrisno, 1975: 11).

From Indonesia, war gamelan is written in an inscription of Java called Waharu IV (913 AD) that mentions......tabéh-tabéhan umiring bala Paduka Sri Maharaja...meaning sounds accompanying the soldiers of Paduka Sri Maharaja (Haryono: 2006, 8). Later in kakawin Bharatayudha, its content is in the form of song that describes the war of Pandavas with the Kauravas, expressed with words sanga-kuda- sudha-tjandrana = Ç 1079 (1157 AD), during Jayabaya's government in Kediri (1135 - 1157 AD). The first part of the story is composed by mpu Sedah and told as far as prabu Salya went to war, then continued by mpu Panuluh. In Canto X number 8 , Prohibitions to attack those who carry mredangga (gamelan), carrying the flag, and that has put the weapon (knuckle) down are mentioned. The word mredangga mentioned here can be the name of an instrument or an orchestra (gamelan).

The word gamelan comes from Javanese gamel which means hitting / beating. The word gamel followed by suffix -an which makes the word gamelan into a noun. The word gamelan literally at this moment is defined as a group of instruments that formed as an orchestration. In various old texts only some that include the word gamelan, the texts only mentioned the names of groups of instruments, but sometimes just one instrument only. In Sunda and Bali, the term gamelan is called the gambelan. In Sundanese gamelan is known as tatabeuhan and in Bali known as tabeh-tabehan. Some estimate that the word gamel comes from Gambel (http://belanagari.wordpres.com, accessed on July 26, 2013), which in Javanese language means tool for beating. The author believes that the word gamelan as well as karawitan (music) is a Javanese word that then spread throughout the archipelago. In Sundanese society, the term to designate a set of musical instruments, simply called by its name alone, for example Degung, Calung, Angklung, Karinding. Likewise with the Balinese people who call a set of instruments that use the gong (gong instrument) by simply calling the name only as Gong Kebyar (Gamelan Gong Kebyar), Gong Gede, Angklung, Balaganjur, and so forth. As with most of the music community in Indonesia people do not recognize that the music of Kolintang, Talempong, Gondang in Kalimantan and others are called with karawitan

In ancient texts, the word gamelan was only mentioned in the younger group of manuscript that is at Kidung Malat (1756) as many as twenty-one starting from sarga XXIX until sarga CI (Jaap Kunst, 1968: 109-113). The manuscript Panji Kuda Narawangsa also mentioned seven times ranging from sarga II until LXXII. Serat Kanda called three times. While in Sewagati manuscript the word gamelan was written into gegamelan called twice, and the last in 
the script of Sorandaka the word gamelan called twice (Jaap Kunst, 1968: 110-113). The word gambelan also contained in the manuscript of Malat Parikan. There are three gamelan words located in Canto I (Durma) numbers 50 and 51, Canto V (Sinon) no. 2 (I Gusti Ngurah Bagus and Wayan Sutapa, 1982: 52, 58, and 125, and 146). Considering the above various interpretations, the occurrence of the word gamelan (gambelan) is estimated younger than words tabeh-tabehan or tetabuhan or around the middle of the 18th century or around 1756 by the release of the kidung Malat, and continued to grow then as expressly provided in Malat Parikan.

The interesting understanding of gamelan comes from an internet site translated as the following. Gamelan is a term for various types of orchestra in Indonesia. This is a key element of traditional Indonesian music. Each gamelan is different from one another, however, all the gamelan has the same organization, based on the different instrumental groups functioning with particular orchestra. Instruments in the gamelan consist of a set of tuned bronze gongs, chime-gongs, metallophones, drums, one or more flute instruments, stringed instruments, and sometimes there are singers. Sometimes some bronze gamelan in the village are replaced by iron, wood, or bamboo gamelans. The most popular gamelan can be found in Java, and Bali (http://www.seasite.niu.edu/ accessed on 19 December 20014, 10:14 hours GMT).

The word gamelan in Indonesian dictionary is interpreted as Javanese musical instrument devices (Sunda, Bali, etc.) consisting of saron, bonang, xylophone, fiddle, drums, gongs, and so on (KBBI: 1996: 288). The term gamelan refers to the instrument / tool, which is a unified whole that is realized and sounded together. Gamelan orchestra are mostly located on the island of Java, Madura, Bali and Lombok in Indonesia in various kinds of sizes and ensemble shapes. In Bali and Lombok today, and in Java through the 18th century, the term gong is considered synonymous with gamelan. This understanding sounds very narrow, so it needs to be expanded not only in Java, Sunda, and Bali but may be expanded into Indonesia. Then the instrumentation is not only narrowed as in Javanese gamelan instruments, but the instruments that exist in Indonesia. Based on the diverse understanding of the gamelan, the author formulates the notion of gamelan as Indonesian original music orchestration (group or can also be a single instrument) composed of melodic instruments and rhythmic instruments.

The word war, according to Kamus Besar Bahasa Indonesia (Indonesian dictionary) is a great battle between the two armed forces (army, paramilitary, insurgent, and so on) or more. War is a physical and non-physical act (in the narrow sense, is a state of hostility with the use of force) between two or more groups of people to perform dominance in the region disputed. In old days, war was interpreted as armed conflict. In the modern era, the war is more directed to technological and industrial superiority. The war discussed in this paper is a war that is interpreted as conflicts of weapon or fighting between two or more conflicting forces.

In Babad Tanah Jawi indicates explicitly the use of gamelan instruments related to war as follows. In another occasion the word bende is also mentioned as ...... When the morning came Adipati Sastra Negara and his men arrived. Roar of cheers and pounding of bendes approach fortress (Olthof, W.L., 1941: 426). According to the excerpt above, the sound of bendes will be followed by cheering of exciting soldiers.

An inscription named Blanjong inscription is the first inscription recording the occurrence of wars in Bali as listed in the fifth line A sides, namely rah $d i$ gurun di s(u)wal duhamalahang musuhdhho...ngka...(rana)...(tah) di kutara... in the third line of the $B$ side (bhayebhirowi)...(bhe)ri...na(bhu) pa(ça) (çi)na (r)agatwa... is written explaining the existence of gamelan Gong Beri. But because of the damage in Blanjong inscription on the experts can only estimate the contents of the translation. There are two sides of writings called side A and side B. Narendra found that the A side of Blanjong inscription reads: In the Year 835 saka Phalguna month, a king who has the power all over the world reigned in Singadwala palace, named Sri Kesari who had defeated their enemies in the deserts and Swal. On the B side: a translation of the inscription on it, the words budha(ç)a.../ nah krtih walidwipa, mean that the entire island under the protection of Buddha. .... (Bhe) ri .... is interpreted as Gong Beri and may have been a great battle. Samasta samanthadhipatih Çri 
Kesari warmma(dewa)..... is interpreted as Adipatih Sri Kesari Warmadewa who became the ruler of the world (Shastri, 1963: 29). Tara Wiguna for side A has the same opinion, while for side $\mathrm{B}$ is equal to side A only the title of king more is fully legible to be Adipatih Çri Kesari Warmadewa. It was also mentioned that due to the king's victory Crri Warmadewa Kesari was said to have mastered the entire Walidwipa. Bacause of the victory, finally an inscription monument was established (Wiguna, 1990: 29-30). Furthermore, the orchestra signaling war is expressed in the manuscript of Wedhapradangga that existed at the time of the Hindu culture, it was reported that during the reign of Sri Maharaja Kano in 338 he had a desire to make a gamelan pedengan in which the instrument consists of: kala, sangka, gubar, gurnang, bairi, puskur, thong-thong, grit, teteg, maguru gangsa like kemodhong. Hence, in Java there are gamelan for war (Prajapangrawit, 1990: 9).

In Balinese-Indonesian dictionary, Gong Beri is interpreted as flat gong without pencon, used to give the spirit in the battle (Warna, 1998: 4). Colin McPhee reveals that bheri is another name of bende now (McPhee, 1966: 367). It certainly can not be approved by the state of gamelan in Bali, because until now there are still bende instrument that is a gong with "flat" pencon. In Java and Sunda, the word bende is interpreted as an instrument of small gong with very loud voice is and in Bali is known as gamelan Tawa-tawa that is the name of the main instruments in the gamelan Tawa-tawa and gamelan Balaganjur.

The structure of traditional Balinese dance consists of pepeson (dance discharge scene), pengawak (scene of dance body parts), pesiat (scene of conflicts or fights), and pekaad (scene of the last part), and is believed to have lasted and have a very long time as well as the art of Karawitan Bali. In the structure of the dance, pesiat (fights) section is usually with bebatelan the musical composition, or with fast rhythms and sounds heroic passionate. Earlier in section pengawak, in order to arrive at pesiat part there is gending composition named pengadeng, which means preparation towards the pesiat (fights). Pengawak and pengadeng are symbols that were agreed by a music composer with a choreographer to do something good in the music and its dance. Just as in Babad Tanah Jawi as follows. ... After the traveling was near Grompol and then bendes were struck and cheering.

Soldiers of Prince Dipa Negara Geger, then take alert on the line ... (McPhee, 1966: 367). In Bali, there are names of dance that showcase dance skills of the soldiers named Baris dance. The name of Baris dance is customized with the name of weapons exhibited such as Baris Tumbak, which demonstrates the skill to play with spears and so on. Obviously this dance depicts a military formation.

\section{Mrdangga As War Gamelan}

Mredangga, mrdanga, merdangga, the word written in Latin script like this, is translated into a variety of senses and meanings, one of which is gamelan or the name of a gamelan. Gamelan is defined as a set of musical instruments for instance in kakawin Bharatayudha Canto X no. 8 concerning the prohibition of killing those who carry mredangga (gamelan), carrying the flag, and who has put weapons and surrendered (Wirjosuparto 1968: 75 and 211). On the other hand, the word mredangga is also an instrument, for example in kekawin Bharatayudha the so-called tabeh-tabehan mredangga kalaçangka, or Nagarakretagama Canto LXXXIV 2, mentioned the word mrdanga, padahi, çangka, tarayan, trut. The word mrdanga is interpreted as gong. Kunts mentions that mrdanga and padahi are two different types of drums (Jaap Kunts, 1968: 68). Mrdanga seems to refer to the word drum in the form of barrel the same as in India that is used for serious parades (Jaap Kunts, 1968: 38). The understanding outlined by Jaap Kunts reminds us of proverb beating the "drums of war". The word drum according to Indonesian dictionary means a big drum, tambour. Tambour (drum) is interpreted as a musical instrument in the form of long hollow inside logs and on one hole or both are covered by the skin (Lukman, 1996, 308).

The word mrdangga is often followed by the word bheri. In Bali, especially in the traditional village of Renon, the word Bheri is used to describe a name of gamelan, the Gamelan Gong Bheri. Gamelan Gong Bheri is currently used to accompany the Baris China dance. In various ancient manuscripts, Gamelan Gong Bheri besides functioning as gamelan war, also serves to honor the coronation and highest warlords in the country. The war Gamelan is assumed to be very easy to be moved in 
aaccordance with the needs of the war itself. Gamelan signing of war is expressed in the manuscript of Wedhapradangga existing at the time of the Hindu culture, it was reported that during the reign of Sri Maharaja Kano in 338 he had a desire to make a gamelan pedengan instrument consisting of: kala, sangka, gubar, gurnang, bairi, puskur, thong-thong, grit, teteg, maguru gangsa like kemodhong. In Java there are gamelan for war (Prajapangrawit, 1990: 9). What is written in the script of this Wedhapradangga is hard to believe since the name of the king, Sri Maharaja Kano as well as the year 338 as in Java the oldest written document concerning a kingdom is 5th century AD. However, since this is about the war gamelan, so whatever small the information about war gamelan will be presented and then the authenticity of its contents is criticized

The author in this section, just reviewed the words Bheri and Mrdangga from two ancient texts and manuscripts, i.e kekawin Bharatayudha and Negarakretagama both of which have been translated into Indonesian by previous researchers. The use of these two sources in addition to letting the facts speak is also intended to facilitate the writing of this article because of the limited time. Actually, for initial search in addition to the word mrdanga and bheri, another word was also found for war to express word war gamelan such as ganjuran, tambur, bedug, and carabalen. The word Ganjuran spread from the inscriptions in Bali, Negarakretagama script, and at this time the gamelan Ganjuran is transformed into Balaganjur or Kalaganjur. The word tambur and carabalen are scattered in old manuscripts but this much younger than the manuscripts revealing the word mrdanga.

\section{Mredangga and Berry in Kakawin Bharat- ayudha}

In Kakawin Bharatayudha, the word mrdangga is first mentioned in Canto IX number 10 as follows.

Sampun mangka tumut Kreshna saha ratha suwarna pajeng çweta warnna.

Lilaningkah ri lampah para ratu pinantih sang watek Parthiwakweh.

Cakra mwang çangka tan sah mareki sira padabra matengrang kagendra.

Yekanghrik ghurniteng ambara siniringan i jrahni hungning mredangga.
Free translation:

When Krishna followed behind, he sat in a Chariot with white umbrella. He arranged the trips of kings as the leader of small kings in the world. The glittering chakra and çangka was held by hand with a flag with a picture of Kagendra. Thunderous shouts of cheers filled the air mixed with the sound of mrdangga (Wirjosuparto 1968: 72 and 207).

Secondly, the word mrdangga is contained in Canto $\mathrm{X}$ number 8 as follows.

Rikan padda ghumoshanan i sawateknya sowang pareng.

Sinantwa sinilan ri sangmukani sang prawireng ranna. Ri tan hananing amrangamawa mredangga tunggul kunang.

Lawan gatinikang katon mawusananggego sanjata.

Free translation:

To respective family and in front of those heroes who were on the battlefield were given an explanation and told that there is no prohibition to attack those who carry gamelan. Those who are carrying flags and also those who have laid down their arms (Wirjosuparto 1968: 111 and 255).

Thirdly the word mrdangga is in Canto XIX number 21, which reads:

Ndatita sira sang paratra malabuh bahni tengahning ranna.

Nda warnan ta muwah pamuk para watek yodherikang paprangan.

Kawasrang manulup ri çangka nira sowang mwang mrdangga selur.

Yanggyaken ri manahnikang bala saharsamuk mawa tah muwah.

Free translation:

It is not told about Hidimbi who has plunged into a fire on the battlefield. It will be narrated again about the soldiers who had been on a rampage on the battlefield. They fought each other. While each of them blew the snail trumpet, mrdangga (gamelan) struck continu ously. It accelerates the birth of joy in their hearts who attack and stampedes (Wirjosuparto 1968: 111 and 255).

Fourth, the word mrdangga is in stanza XXXIX number 2 which reads:

Para ratu sang samangdulura kapwa teka padda marek. Saha bala kosha wahana matingkah arepat ahalep. 
abeh-tabehan mredangga kala çangka humung asahuran.

Pinarenganing prawira wijah atri gumuruh anguhuh.

Free translation:

The kings who will accompany have come and stay nearby, complete with troops and boxes (containing provisions of war). While the chariots have been prepared earlier, so it looks completely beautiful. All the sounds, the orchestra and snail trumpets are stared and inflated, so boisterous and accompanied by noise. Fanfare and crowded athmosphere are created by the heros with thundering cheers (Wirjosuparto 1968: 151 and 318).

Fifth, the word mrdangga is in Canto XIX number 6, which reads:

\section{Paddasira-siran mamukti wisyamangan anginun anamtan indriya}

Mredangga karengo nirantara muning sakuwu kapta ghurnita.

Bangun manguhuhajara $n$ hela-hela marawaça ripu çakti ring ranna.

Tuwi pwa tahu garwwa matta rasa tan pabalika kaparajayanjaya.

Free translation:

They were together to rejoice and enjoyed their physi cal enjoyment; they were eating and drinking while giving satisfaction to the senses. Gamelan were sound edendlessly in each camp and each paced frenzy. The sound of the orchestra is as if echoing and will lead them to destroy supernatural enemies on the battle field. Similarly, they were truly excited and half crazy because of the victory, so that they feel that they will not go back into the valley of defeat from those who have perished (Wirjosuparto 1968: 170 and 343).

\section{Mrdangga As Symbolic Representation of Grandly King}

The book of Negarakertagama, cantos 31 , number 3 indicates:

ikan widi widana sakrama tlas / gnep sankepan, makadyan upabhoga bhojana halp nikanopama, amatya gana samyasanghya çagiri datan rin sabha, mrdanga padahatri megeliglan mahinan dina.

Free translation:

The ceremony took place keeping all rules and regula tions. It starts with a festive banquet. The patihs are parading Majesty towards paseban. Mrdangga (drums) and padaha vibrate following the motions.

The book of Negarakretagama cantos 83

Negarakertagama number 6 writes:

tinkahnin pujan idran / bhrisadi saha mrdangenarak

nin wan akweh, pin pitwanken dinaimbuh sasikhi saha niwaidyan dunun rin wanuntur, homa mwan

brahmayajnenulahaknira san çewa boddan pamuja,

amwit in astami krsna makaphala rikan swasthana çri narendra.

Free translation

The mredangga on doolie is taken whirling around in a crowded folk procession. When mredangga is already beaten seven times, the offerings are taken to the temple. Victims of the fire, mantra reciting are done by Siwa-Buddha priest starting in the evening, eight of the month for the sake of the king safety.

The book of Negarakretagama cantos written 84 number 2 indicates:

ghurnan padata mrdanga trutika dudun çanka tarayan atri, sinran ni paselur in bhattagana manuccaranan abhiwada, çlokhastutinira sanken parapura de san nipuna kawindra, cihna nrpati gahan / lwi raghusuta krsnanjaya subhagen rat.

Free translation:

The thundering echo of mredangga and trut (a type of trumpet), was greeted by rousing trumpet concat enated. The moving row of poets welcomed him with puja sloka. Composed by royal Kawi from various cities of Java. His devotion is just like Rama, noble like Sri Krishna.

\section{War Gamelan in the Manuscript of Kidung Ranggalawe}

Canto VI No. 13 writes the word gong, percussion and gending as follows.

Saha gong tabuh-tabuhan, gending dhwaja sapangac areng jurit, rahadyan asemu guyu, iya yayi sareha, sinariraken ing sira tatanipun, sangwinuwusun atur bhakti, sawadinipunsinggih.

Free translation:

The gong and the sounds, gamelan pennants and all the actions of soldiers, a smile on Raden face, yes dear please be patient, have a rest regularly, the addressee paid homage, actually approved. 
Canto VI number 29 indicates the word tetabuhan as follows.

Tinut rahadyan sang ing $W i$, rasabha mantuk aturangga sami, sang mantri abhyasaken tu, -rangga sinrama-sraman, tinon yayeng tulis sakamarga umung, sawara ning tatabuhan byakta, -mangun durmitteng gati.

Free translation:

Follow Raden in Wirasabha, return and all ride horses, the Secretary was well trained to ride horse, playing war game, it looks as though describing the path filled with boisterous, gamelan voice / sounds, that built a bad feeling right now.

\section{CONCLUSION}

Of the various statements above, it could be concluded that the War Gamelan means a group of instruments used in warfare. Its function in addition to providing greater enthusiasm to the soldiers to do the fighting, it is also a communication tool or giving orders to soldiers to do something related to the formation or tactics of warfare.

Soetrisno found the word mredangga originally means drums, then it means a set of gamelan, and ultimately means gamelan players or niyaga (Soetrisno, 1976: 18). This opinion can be justified because the word Mredangga in various old manuscripts contain a lot of sense depending on the poetic sentence where the word mredangga is located. The word mredangga word can stand alone as a group of instruments or accompanied by other words that mention other instruments. But the signification and the meaning of mredangga, should be in line with words that go with it as the word gurnita, kumeretug (thundering), gumuruh (rumble), dark atarung (like the sound of fighting thunder) and a loud sound between the sound of other musical instruments. The word Mredangga partly has been lost after the script in the form of kidung like kidung malat that is replaced with the name of bedug (drum), except in Kidung Sunda contained in Zang I number 128 that tells said awor mrdangga (echoeing sound of mrdangga) and subsequently replaced with tambur to illustrate the gamelan instruments of war.

As a gamelan that serves to give the spirit of the war, of course war gamelan has the function to generate a physical response, such as attacks on the enemy.
War Gamelan makes someone who heard it more eager to do something beyond his ability. In practice, the war gamelan must be beaten in a mobile or moveable quickly following the direction and movement of troops. War gamelan is used to prepare for war, during the wars (giving encouragement), and of course for the victory celebration in the battle.

\section{REFERENCES}

\section{Books:}

Ankersmit. 1987. Refleksi Tentang Sejarah, pendapat-pendapat modern tentang Filsafat Sejarah.(terjemahan), penerjemah Dick Hartoko, Jakarta: PT Gramedia.

Fernandus, Pieter Eduard Johannes. 2004. Alat Musik Jawa Kuno. Yogyakarta: Yayasan Mahardhika.

Garaghan, S.J. Gilbert. 1957. A Guide to Historical Method, edited by Jean Delanglez, New York: Fordhan University Press, East Fordham Road, Fourth Printing.

Gottschalk, Louis. 1975. Mengerti Sejarah (Pengantar Metode Sejarah), Terjemahan. Nugroho Notosusanto, Jakarta: Universitas Indonesia.

Herlina, Nina. Prof., Dr., MS. 2014. Metode Sejarah. Ed. Revisi, Bandung: Yayasan Masyarakat Sejarawan Indonesia Cabang Jawa Barat.

Hooykaas, C. 1931. Tantri Kamandaka. Een Oudjavaansche Pantjatantra bewerking in Teks en Vertaling. Bandoeng: Bibliotheca Javanica 2.

Kartodirdjo, Sartono. 1982. Pemikiran dan Perkembangan Historiografi Indonesia, Suatu Alternatif. Jakarta: PT Gramedia.

Kuntowijoyo. 2003. Metodologi Sejarah. Edisi kedua, Yogyakarta: Diterbitkan atas kerjasama dengan Jurusan Sejarah Fakultas Ilmu Budaya Universitas Gadjah Mada, PT Tiara Wacana Yogya.

Kunts, Jaap. 1968. Hindu Javanese Musical Instruments. The Hague: Martinus Nijhoff. 
Olthof, W.L. 1941, Punika Serat Babad Tanah Jawi Wiwit Saking Nabi adam Doemoegi in taoen 1647. Terjemahan, H.R. Sumarsono, Yogyakarta: Penerbit Narasi.

Prajapangrawit, R. Ng. 1990. Serat Sujarah Utawi Riwayating Gamelan Wedhapradangga (Serat Saking Gotek). Surakarta: kerja sama STSI Surakarta dengan The Ford Foundation.

Renier GJ. 1997. History its Purpose and Method, terjemahan Prof. Drs. Muin Umar: Metode dan manfaat Ilmu Sejarah. Yogyakarta: Pustaka Pelajar.

Sedyawati Edi. 1985. Pengarcaan Ganesha Masa Kadiri dan singhasari: Sebuah Tinjauan Sejarah Kesenian. Disertasi. Jakarta: Universitas Indonesia.
Wirjosuparto, R.M. Soetjipto. 1960. Kakawin Ghhatotkacaçraya, Tjerita Lakon dalam Bahasa Kawi. Disertasi Doktor dalam ilmu sastra, Fakultas Sastra, Universitas Indonesia.

1968. Kakawin Bharata-Yudha, Djakarta: Penerbit Bhratara.

\section{Internet}

http://belanagari.wordpres.com, diakses tanggal 26 Juli 2013 jam 08.00 WIB

http://id.wikipedia.org/wiki/Gamelan, di lihat tanggal 19 desember 2014 pada jam 08.35 WIB.

http://id.wikipedia.org/wiki/Perang, diakses tanggal 19 Desember 2014, jam 10.25 WIB.

http://www.seasite.niu.edu/ Diakses pada tanggal 19 desember 20014, jam 10.14 WIB. 